\title{
SERUM BETA CROSSLAPS AS A PREDICTOR FOR OSTEOPOROSIS IN POSTMENOPAUSAL WOMEN
}

\author{
POSTMENOPOZAL KADINLARDA OSTEOPOROZU ÖNGÖRMEDE \\ SERUM BETA CROSSLAPS
}

\author{
Murat ARSLAN*, Ebru ÇÖĞENDEZ**, Meryem EKEN**, Petek Feriha ARIOĞLU***, \\ Sadiye EREN****
}

\begin{abstract}
Objective: To evaluate bone turnover by an early marker, CrossLaps (beta-CTx), in postmenopausal women receiving hormone replacement therapy (HRT) or bisphosphonates (BP) to reduce bone loss.

Materials and methods: Thirty patients with no menstruation for at least one year, FSH $>40$ IU/L, estrogen $<20 \mathrm{ng} / \mathrm{mL}$ at the time of presenting to Zeynep Kamil Women and Children's Training and Research Hospital were included in this study. The patients were divided into two groups, the HRT group and the BP group. In the HRT group (n=12), patients were prescribed $1 \mathrm{mg}$ estradiol, $0.5 \mathrm{mg}$ norethisterone acetate and $1000 \mathrm{mg}$ calcium $(\mathrm{Ca})$ daily for 6 months. In the BP group ( $\mathrm{n}=18$ ), patients were given 70mg alendronate weekly for 6 months. Bone density was evaluated using dualenergy X-ray absorptiometry at the beginning of the study and after six months. T-scores were used for the quantitative evaluation of bone loss. At the beginning and at the end of the six months, serum Beta-CTx levels were measured. Differences in the T-scores and serum beta-CTx levels of the study groups were compared.

Results: The T-scores of patients who received BP were significantly higher compared with those of patients on HRT at the beginning of the study $(\mathrm{p}<0.01)$. The T-scores of patients who received BP were significantly higher than those on HRT at the end of six months $(\mathrm{p}<0.05)$. Within either group, the T-scores at the beginning and at the end of six months were not statistically significantly different $(\mathrm{p}>0.05)$. The serum beta-CTx levels of patients who received BP were significantly higher compared with those on HRT at the beginning of the study $(\mathrm{p}<0.01)$. Beta-CTx levels were also higher compared with patients receiving HRT after the six-month period $(\mathrm{p}<0.05)$. The serum beta-CTx levels were significantly lower at the end of the six months in patients who received BP compared with the levels at the beginning $(\mathrm{p}<0.05)$.

Conclusion: Changes in serum beta-CTx measurements are detectable earlier than warning signs in bone mineral densitometry and may be a better guide to follow the effectiveness of treatment, especially in patients with high bone turnover; however, long-term studies are required for standard clinical use.
\end{abstract}

Key Words: Serum Beta-CrossLaps; menopause; osteoporosis.

\section{ÖZET}

Amaç: Postmenopozal kemik yıkımını azaltmak amacıyla hormon replasman tedavisi (HRT) veya bifosfonat (BP) tedavisi verilen hastalarda tedavi sürecinde kemik yıkım hızının güncel bir marker olan serum crosslaps $(\beta-C T x)$ ile değerlendirilmesi.

Gereç ve yöntemler; Zeynep Kamil Eğitim Araştırma Hastanesi polikliniğine başvuran en az bir y1l süredir menstruasyonu olmayan, Follikül Stimulan Hormon değeri (FSH) $>40$ IU/L Östrojen (E2) < 20ng/ml olan 30 hasta çalışmaya dahil edildi. Araştırmaya katılan hastalar, HRT alan ve BP tedavisi alan olmak üzere iki gruba ayrıldı. HRT alan gruptaki $(\mathrm{n}=12)$ hastalara 6 ay süre ile günlük $1 \mathrm{mg}$ estradiol, $0.5 \mathrm{mg}$ norethisterone acetate ve $1 \mathrm{gr}$ kalsiyum (Ca) tedavisi verildi. BP alan gruptaki $(\mathrm{n}=18)$ hastalara ise 6 ay süre ile haftalık $70 \mathrm{mg}$ alendronat ve $1 \mathrm{mg}$ Ca tedavisi verildi. Başlangıçta ve 6. ay sonunda tüm hastaların kemik yoğunluğu ölçümü dual-enerji X-ray absorbsiyometri (DEXA) kullanılarak yapıldı. Hastaların T skorları kemik yıkımının kantitatif değerlendirilmesi için kullanıldı. Başlangıçta ve 6.

Date received/Dergiye geldiği tarih: 30.12.2014 - Date accepted/Dergiye kabul edildiği tarih: 11.03.2015

* $\quad$ Sivas Goverment Hospital Obstetric and Gynaecology Department, Sivas, TURKEY

** Zeynep Kamil Education and Research Hospital, Obstetric and Gynaecology Department, Istanbul, TURKEY

$* * *$ Private practice

**** Private Medistate Hospital Obstetric and Gyneacology Clinic, Istanbul, TURKEY

(Corresponding author/İletişim kurulacak yazar: meryemkurek@yahoo.com) 
ay sonunda serum $\beta$-CTx seviyesi ölçüldü. Hasta gruplarının 6. ay sonundaki T-skorlarındaki değişim ile serum $\beta$-CTx değişimleri karşılaştırıldı.

Bulgular: BP kullanan olguların başlangıç T-skoru düzeyleri, HRT kullanan olgulara göre anlamlı yüksekti ( $\mathrm{p}<0.01)$. BP kullanan olguların 6. aydaki T skoru düzeyleri, HRT kullanan olgulardan anlamlı düzeyde yüksek bulundu ( $\mathrm{p}<0.05$ ). Her iki grupta da; başlangıçtaki T skoru düzeyine göre 6. ay T skoru düzeyinde istatistiksel olarak anlamlı bir değişim görülmemiştir $(\mathrm{p}>0.05)$. BP kullanan olguların başlangıçtaki $\beta$-CTx düzeyleri, HRT kullanan olgulardan anlamlı yüksekti $(\mathrm{p}<0.01)$. BP kullananların 6. aydaki $\beta$-CTx düzeyleri, HRT alanlardan anlamlı düzeyde yüksek bulundu $(\mathrm{p}<0.05)$. BP kullanan olgularda; başlangıçtaki $\beta$-CTx düzeyine göre 6 . ay $\beta$-CTx düzeyinde görülen düşüş istatistiksel olarak anlamlı bulunmuştur $(\mathrm{p}<0.05)$.

Sonuç: Serum $\beta$-CTx ölçümü erken dönemde değişim göstererek özellikle hızlı kemik kaybı olan hastalarda tedavinin etkinliğini değerlendirmede kemik mineral yoğunluğuna göre daha erken yol gösterici olmakla birlikte bu konuda daha uzun süreli çalışmalara ihtiyaç vardır.

Anahtar Kelimeler: Serum Beta crosslaps; menopoz; osteoporoz

\section{INTRODUCTION}

Osteoporosis is characterized by low bone mass density and micro-architectural deterioration, which increase the risk of bone fractures and result in pain and deformity. Osteoporosis is considered a significant public health concern that will increase in the future as the population ages in the developed world (1).

Bone mineral density (BMD) is the most important predictor of fracture risk. Other contributing factors to bone strength, some of which are heritable, include bone turnover, bone architecture and skeletal geometry (e.g. long femoral necks fracture more easily than short ones) (2). Non-invasive bone mineral density measurements are utilized as a guide both to initiate treatment and evaluate its effectiveness. The current gold standard is still dual-energy X-ray absorptiometry (DEXA), in which $\mathrm{X}$-rays pass through a standardized disc containing absorption material and then through the patient's tissue; absorption in both is measured separately and the evaluation is made by comparing the two measurements. Total body, anterior, posterior, lateral lumbar spine, and femora are measured.

There are many laboratory tests used in the diagnosis and follow-up of bone loss. Beta-CrossLaps (beta-CTx) are the C-terminal telopeptides of type I collagen, the main component (approximately 90\%) of the protein matrix of bone. Beta-CTx is released into the bloodstream during bone resorption and is almost entirely excreted by the kidneys. Its quantification serves as a specific marker for the degradation of mature type I collagen from bone (3).

Prevention of osteoporosis preserves an individual's quality of life as well as reducing the economic burden of treatment. For the prevention of osteoporosis and resulting fractures, it is important to identify women who have a high risk of fracture.

In this study, our aim was to evaluate the rate of bone loss by an early marker, serum beta-CTx, in postmenopausal women receiving either hormone replacement therapy (HRT) or bisphosphonates (BP), and predict response to treatment at an earlier stage.

\section{MATERIALS AND METHODS}

Our study was designed as a prospective randomized study at the gynecology clinic of our Hospital, recruiting thirty patients after obtaining informed consent. The Ethics Committee reviewed and approved the project. Patients had not been menstruating for at least one year, had follicle stimulating hormone (FSH) levels of $>40 \mathrm{IU} / \mathrm{L}$ and estradiol (E2) levels of $<20 \mathrm{ng} / \mathrm{mL}$. All patients had an intact uterus. They had no contraindications to HRT, alendronate or calcium use, and were randomized into two different treatment groups.

For six months, members of the HRT group $(n=12)$ were prescribed estradiol 1mg, norethisterone acetate 205mg, calcium 1000mg daily; the BP group was treated with alendronate $70 \mathrm{mg}$ weekly and calcium $1000 \mathrm{mg}$ daily. At the beginning of the study and after six months, bone mineral density was measured using DEXA. The T-scores of the patients were used for the quantitative evaluation of bone loss. At the beginning and at the end of the six-month period, serum beta-CTx was also measured. Serum beta-CTx was measured in the morning with fasting state blood samples. By measuring morning fasting serum beta-CTx, the variability of measurement was minimized. The method used was electrochemiluminescence immunoassay (ECLIA) Eleycys modular analytic E170. This is an immunologic test for the quantitative analysis of Type 1 collagen metabolites. The T-score and serum beta-CTx changes at the end of the study were compared.

\section{Statistical Analysis}

Number Cruncher Statistical System (NCSS) 2007 \& PASS 2008 Statistical Software (Utah, USA) were used for statistical analyses. Mean and standard deviation were used as descriptive statistical methods in the analysis of the data. When comparing parameters that showed normal distribution between the two groups, Student's t-test was used.- Mann-Whitney U test was used to compare parameters that did not show normal distribution. Wilcoxon sign-rank test was used when comparing the parameters that did not show normal distribution within the group. Spearman's correlation analysis was used to determine the correlations between the parameters. $\mathrm{P}<0.05$ was considered significant.

\section{RESULTS}

The study was carried out with thirty patients aged between 45-57 years. The mean age of the HRT 


\section{Beta crosslaps in osteoporosis}

treatment group was $47.0 \pm 1.27$ years, the BP group was older (51.8 \pm 2.54 years); the difference was statistically significant as a consequence of randomization. The characteristics of the patients are shown in (Table 1). In patients that received BP treatment, the levels of betaCTx were significantly lower at the end of the six month period compared with the level at the beginning $(\mathrm{p}<0.05)$. In patients on HRT, although there was a fall in serum beta-CTx levels at the end of six months, the difference was not statistically significant $(\mathrm{p}>0.05)$ (Table 2).

Table 1: Baseline characteristics of subjects in the two treatment groups

\begin{tabular}{lrrl} 
& BP group & HRT group & p value \\
& Mean \pm SD & Mean \pm SD & \\
\hline Age (years) & $51.8 \pm 2.54$ & $47.0 \pm 1.27$ & $\mathbf{0 . 0 0 1}^{*}$ \\
Body mass index $\left(\mathrm{kg} / \mathrm{m}^{2}\right)$ & $28.10 \pm 3.65$ & $27.12 \pm 3.40$ & $\mathbf{0 . 0 7}$ \\
Duration of menopause (years) & $3.46 \pm 0.98$ & $2.67 \pm 0.92$ & $\mathbf{0 . 0 0 1}^{*}$
\end{tabular}

${ }^{*} p<0.05$ BP: Bisphosphonates; HRT: Hormone replacement therapy

Table 2: Comparison of beta-CTx levels between two groups

\begin{tabular}{lccl} 
Beta-CTx & $\begin{array}{c}\text { BP group } \\
\text { Mean } \pm \text { SD }\end{array}$ & $\begin{array}{c}\text { HRT group } \\
\text { Mean } \pm \text { SD }\end{array}$ & p value \\
\hline 0 months & $0.64 \pm 0.38(0.58)$ & $0.38 \pm 0.21(0.41)$ & $\mathbf{0 . 0 0 1 * *}$ \\
6 months & $0.51 \pm 0.33(0.43)$ & $0.30 \pm 0.25(0.26)$ & $\mathbf{0 . 0 3 4 *}$ \\
\hline
\end{tabular}

Mann-Whitney U test; * $p<0.05 * * p<0.01$

Beta -CTx: Beta CrossLaps; HRT: Hormone replacement therapy;

BP: Bisphosphonates

Table 3 : Comparison of BMD values between the two groups

\begin{tabular}{|c|c|c|c|}
\hline T-Score & $\begin{array}{c}\text { BP } \\
\text { Median } \pm \text { SD }\end{array}$ & HRT Median \pm SD & ${ }^{+} \mathrm{p}$ value \\
\hline 0 months & $-2.81 \pm 0.51(-2.75)$ & $-2.20 \pm 0.40(-2.40)$ & $0.001 * *$ \\
\hline 6 months & $-2.80 \pm 0.67(-2.90)$ & $-2.19 \pm 0.39(-2.30)$ & $0.017^{*}$ \\
\hline${ }^{++}$p value & 0.810 & 0.873 & \\
\hline Difference between 0 and 6 months & $0.01 \pm 0.41(0.2)$ & $0.01 \pm 0.52(0)$ & 0.509 \\
\hline $\begin{array}{l}\text { L1 vertebral spine } \\
0 \text { months }\end{array}$ & $-2.78 \pm 0.78(-2.55)$ & $-1.92 \pm 0.67(-2.05)$ & $0.004^{* *}$ \\
\hline 6 months & $-2.58 \pm 0.90(-2.40)$ & $-1.90 \pm 0.91(-2.30)$ & $0.035 *$ \\
\hline${ }^{++} p$ value & 0.146 & 0.608 & \\
\hline Difference between 0 and 6 months & $0.20 \pm 0.48(0.10)$ & $0.01 \pm 0.45(0.05)$ & 0.483 \\
\hline $\begin{array}{l}\text { L2 vertebral spine } \\
0 \text { months }\end{array}$ & $-3.07 \pm 0.82(-3.05)$ & $-2.29 \pm 0.28(-2.35)$ & $0.005^{* *}$ \\
\hline 6 months & $-3.00 \pm 0.95(-3.25)$ & $-2.49 \pm 0.45(-2.60)$ & 0.102 \\
\hline${ }^{++} p$ value & 0.332 & 0.263 & \\
\hline Difference between 0 and 6 months & $0.07 \pm 0.47(0.15)$ & $-0.20 \pm 0.48(-0.10)$ & 0.105 \\
\hline $\begin{array}{l}\text { Femur Neck } \\
0 \text { months }\end{array}$ & $-1.95 \pm 0.79(-2.2)$ & $-1.86 \pm 0.68(-1.9)$ & 0.671 \\
\hline 6 months & $-1.52 \pm 0.69(-1.9)$ & $-1.87 \pm 0.78(-1.9)$ & 0.359 \\
\hline${ }^{++} p$ value & $0.001 * *$ & 0.856 & \\
\hline Difference between 0 and 6 months & $0.42 \pm 0.36(0.4)$ & $0.00 \pm 0.15(0)$ & $0.001 * *$ \\
\hline
\end{tabular}


The L1-BMD of patients receiving BP treatment at the beginning of the study and after six months was significantly higher compared with those of patients on HRT $(p<0.05)$. When the changes in L1-BMD were compared between the two groups, no significant difference was noted ( $>>0.05)$. L2-BMD of patients receiving $\mathrm{BP}$ treatment at the beginning of the study was also significantly higher compared with the HRT group $(p<0.01)$. There was no significant difference between the two groups in changes of L2- BMD from the beginning of the study until the end of six months (p>0.05) (Table 3).

In the HRT group, femur neck BMD did not change significantly from the beginning to the end of the study $(\mathrm{p}>0.05)$. In patients treated with $\mathrm{BP}$, the change in femur neck BMD over six months was statistically significant $(\mathrm{p}<0.01)$. However, the changes in the femur neck BMD over six months between the two study groups were not statistically significantly different.

At the beginning of the study, the T-scores of patients receiving $\mathrm{BP}$ were significantly higher than in those on HRT $(p<0.01)$. At the end of six months, the T-scores of patients who used BP was significantly higher than in those receiving HRT $(\mathrm{p}<0.05)$. There was no statistical difference between the T-scores at the beginning and after six months in the BP group ( $p>0.05)$, There was no statistical difference between the $\mathrm{T}$-scores at the beginning and at the end of six months in patients who received HRT ( $>0.05)$ (Table 3$)$.

\section{DISCUSSION}

The importance of menopausal estrogen deficiency in the pathogenesis of osteoporosis was first recognized by Fuller Albright in 1941, who observed that most patients with osteoporosis were postmenopausal women (4). Subsequent studies demonstrated that the menopause was associated with bone loss, which could be prevented by estrogen treatment in a dose-dependent manner. Before the licensing of the first bisphosphonates for the treatment of osteoporosis in the 1990s, HRT was the major therapeutic option for both the prevention and treatment of postmenopausal osteoporosis (5).

C-telopeptide CrossLaps (CTX) and bone-specific alkaline phosphatase (BAP) are used as markers for bone resorption and formation and also for prediction of fracture risk, independent of BMD, and monitoring of osteoporosis treatment $(6,7)$.

Bone turnover markers may be used to detect treatment efficacy earlier than DEXA. When antiresorptive or anabolic medication is given, biochemical markers change earlier than physical markers, and this information is helpful in convincing patients to continue their treatment. Bone turnover markers may also be used along with bone density values when beginning osteoporosis medication and to monitor bone turnover when treatment is completed (8).

In a study by Overgaard, nasal calcitonin was given to patients who were diagnosed as having osteoporosis in the postmenopausal period. Patients were followed up at regular intervals for two years. Serum beta-CTx levels and BMD were determined at six, twelve, and twenty- four months. At the end of two years, there was a significant relationship between the changes in betaCTx levels and changes in BMD. Beta-CTx levels decreased as BMD increased (9).

In 1999, the role of biochemical markers in revealing BMD changes was investigated in a multicenter study. Serum beta-CTx, total calcitonin, and bone-specific alkaline phosphatase were investigated as biochemical markers. The relationship between the biochemical marker levels with BMD at the beginning of the study, after six months, and at the end of two years was evaluated. It was shown that early changes in biochemical markers were predictive of BMD changes in the long run (10).

In our study, although there was a fall in serum betaCTx levels in the short term, this was not reflected in long-term BMD changes. The most important reason is that this was a short-term study. Nevertheless, the fall in serum beta-CTx levels in a short period of six months gives us an idea about the effectiveness of treatment. Garnero investigated the role of changes in serum and urinary beta-CTx levels in predicting future osteoporotic fractures. At the end of their study, the authors showed that changes in biochemical markers could predict fracture risk earlier and more accurately (11).

Zao et al. compared bone turnover markers in postmenopausal women and found statistically significantly higher serum beta-CTx levels in patients with a high risk of osteoporotic or vertebral fracture. However, in the same study, there was no relationship between serum P1NP, which is an N-aminoterminal propeptide of type I collagen, and fracture risk; the researchers also found that there was a negative correlation between serum beta-CTx, serum P1NP levels, and bone mineral density (12).

In 2003, Tanko et al. found that serial serum beta-CTx measurements could determine the effectiveness and appropriateness of treatment at an early stage. Twohundred healthy postmenopausal women with T-scores between -1 and -5 were included in the study. Patients were given BP treatment at different doses and frequencies. Serum beta-CTx levels were measured in blood drawn. At the end of this study, they concluded that serial beta-CTx measurements were found to be helpful in determining the effective dose at a very early stage, whereas it took at least a year with BMD to achieve this aim (13).

In 2009, in a randomized, double-blind, placebo controlled study conducted by Rogers et al, the role of biochemical markers in determining the effectiveness of lasofoxifene treatment was investigated. Serum betaCTx levels at $0,6,12$, and 24 months were measured, and BMD was evaluated at 12 and 24 months. In the treatment group, serum beta-CTx levels fell at 6 months. The changes in BMD were not detectable before one year (14).

In our study, we evaluated both serum beta-CTx levels and BMD of patients after six months of treatment. There was no change in BMD; however, serum betaCTx levels fell in $70 \%$ of all cases. In light of these findings, we concluded that serum beta-CTx 
measurement was more effective than BMD in the early assessment of osteoporosis and follow-up treatment.

Although BMD is not sufficient to evaluate effectiveness of treatment before one year has elapsed, serum beta-CTx can assess treatment as early as six months. Furthermore, the early change in serum betaCTx gives information about later bone gain (15).

In our study, the fall of serum beta-CTx levels the in the HRT group was not significant, but it was statistically significant in the BP group. No change was observed in any of the parameters of BMD at the end of six months; these findings reveal that assessment of treatment effectiveness is more effective with serum beta-CTx levels compared with

BMD.

\section{CONCLUSION}

We evaluated serum beta-CTx levels and BMD in patients after six months of treatment for osteoporosis. We observed none of the long-term changes in BMD described in other longer-term studies. It takes at least one year to observe changes in BMD.

On the other hand, this approach seems to be more effective than BMD in assessing osteoporosis treatment because changes in serum beta-CTx levels can be detected much earlier.

In conclusion, serum CrossLaps measurement is an earlier marker and guide compared with bone mineral densitometry in assessing the effectiveness of osteoporosis treatment, especially in patients with rapid bone loss. Further long-term randomized controlled trials are required to fully clarify this subject.

\section{REFERENCES}

1. McCombs JS, Thiebaud P, McLaughlin-Miley C, Shi J. Compliance with drug therapies for the treatment and prevention of osteoporosis. Maturitas. 2004;48:271-87.

2. Anna Daroszewska. Prevention and treatment of osteoporosis in women: an update. Obstetrics, Gynaecology \& Reproductive Medicine. 2012;22:162-9.

3. Peichl P, Griesmacherb A, Marteau R. et al. Serum crosslaps in comparison to serum osteocalcin and urinary bone resorption markers. Clinical Biochemistry 2001;34:131-9.

4. Albright F, Smith PH, Richelson AM. Postmenopausal osteoporosis: its clinical features. JAMA 1941;116:2465-74.

5. Bowring CE, Francis RM. National Osteoporosis Society's Position statement on hormone replacement therapy in the prevention and treatment of osteoporosis. Menopause Int. 2011;17:63-5

6. Garnero P. New biochemical markers of bone turnover. IBMS Bone Key 2008;5:84-102.

7. Vasikaran S, Eastell R, Bruyère $O$, Foldes AJ, Garnero P, Griesmacher A et al. IOF-IFCC Bone Marker Standards Working Group. Markers of bone turnover for the predictionof fracture risk and monitoring of osteoporosis treatment: a need for international reference standards. Osteoporosis International 2011;22:391-420.
8. Vasikaran S, Cooper C, Eastell R, Griesmacher A, Morris HA, Trenti T et al. International Osteoporosis Foundation and International Federation of Clinical Chemistry and Laboratory Medicine position on bone marker standards in osteoporosis. Clin Chem Lab Med. 2011;49:1271-4.

9. Overgaard K, Christiansen C. A new biochemical marker of bone resorption for follow up on treatment with nasal salmon calcitonin. Calcif Tissue Int 1996;59:12-6.

10. Ravn P, Clemmesen B, Christiansen C. Biochemical markers can predict the response in bone mass during alendronate treatment in early postmenopausal women. Bone 1999;24:237-44.

11. Garnero P, Delmas PD. Contribution of bone mineral density and bone turnover markers to the estimation of risk of osteoporotic fracture in postmenopausal women. J Musculoskel Neuron Interact 2004;4:50-63.

12. Zhao J, Xia W, Nie M, Zheng X, Wang Q, Wang X et al. The levels of bone turnover markers in Chinese postmenopausal women: Peking Vertebral Fracture study. Menopause. 2011;18:1237-43.

13. Tanko LB, Mouritzen U, Lehmann HJ, Warming L, Moelgaard A, Christgau S. Oral ibandronate: changes in markers of bone turnover during adequately dosed continuous and weekly therapy and during different suboptimally dosed treatment regimens. Bone 2003;32:687-93.

14. Rogers A, Glover SJ, Eastell R. A randomised, double-blinded, placebo-controlled, trial to determine the individual response in bone turnover markers to lasofoxifene therapy. Bone 2009;45:1044-52.

15. Christgau S, Bitsch-Jensen O, Hanover BN, Gamwell HE, Ovist P, Alexandersen P. Serum Crosslaps for monitoring the response in individuals undergoing antiresorptive therapy. Bone 2000;26:505-11. 